\title{
ВПЛИВ ОСВІТИ НА ФОРМУВАННЯ КРЕАТИВНОГО ЛЮДСЬКОГО КАПІТАЛУ
}

\author{
Поснова Т. В. к. е.н. \\ Україна, Ірпінь, Університет державної фіскальної служби України, дочент кафедри \\ економічної теорії
}

DOI: https://doi.org/10.31435/rsglobal_ijite/01062018/5664

\section{ARTICLE INFO}

Received 04 April 2018

Accepted 18 May 2018

Published 01 June 2018

\section{KEYWORDS}

creative human capital, creative economy, education system

\begin{abstract}
The article describes the influence of education on the formation of creative human capital. It is justified that education has a significant impact on the formation, reproduction and development of creative human capital. The paper also analyzes the state of the educational level of citizens and innovative development in Ukraine compared to other countries of the world. The work states that it is necessary to reform the modern educational system in order to provide the appropriate level of training of professionals, in which knowledge, skills and abilities will meet the requirements of the creative economy. As recommendations the article presents the main directions of the modern system of education that will be able to provide effective formation of creative human capital, in particular: creation of conditions for development of creative, independent and socially responsible person who is professionally competent; integration of educational and cultural components, a combination of training, education and research work; development of a creative environment that stimulates pupils and students to form an active life position in order to implement their personal and creative potential.
\end{abstract}

Вступ. Особливістю сучасного розвитку постіндустріального суспільства є прискорення науково-технічного прогресу, автоматизація та роботизація виробничих процесів, зміна ролі та місця людини у цих процесах, у зв'язку з чим виникає необхідність дослідження відносно нової економічної категорії - креативного людського капіталу та його залежності від рівня та якості освіти. Освіта та інновації - один 3 найбільш важливих напрямків 3 точки зору довгострокової перспективи будь-якої країни, ії потенціалу та конкурентоспроможності у умовах формування креативної економіки.

Проблемі розвитку інтелекту та креативності присвячено багато наукових праць вітчизняних та зарубіжних дослідників, таких як Б. Г. Ананьєв, Л. І. Анциферова, Л. А. Баранова, В. М. Бехтерев, Д. Б. Богоявленська, Л. І. Божович, Ф. Гальтон, Дж. Гілфорд, А. С. Грузенберг, Д. Б. Ельконін, Г. С. Костюк, А. А. Кроник, Н. С. Лейтес, Н. А. Логінова, К. М. Гуревич, Т. Любарт, М. А. Мергалієва, В. О. Моляко, І. П. Павлов, К. К. Платонов, I. С. Сумбаєв, Б. М. Теплов, Е. П. Торренс, Х. Е. Трік, Ф. Шеллінг, Т. Шульц та інших. Однак, з економічної точки проблема впливу освіти на формування креативного людського капіталу $є$ малодослідженою.

Результати дослідження. В умовах формування креативної економіки, одним із пріоритетних стає питання підготовки професіоналів, знання, вміння та навички яких відповідають потребам сучасної економіки. Відносини між вищою освітою та креативним капіталом в першу чергу мають зв'язок з управлінням людським капіталом через формування та розвиток навичок, знань та творчих здібностей людини.

Теоретики людського капіталу стверджували, що якщо рівень освіти людей високий, то це $з$ високим ступенем ймовірності призведе до економічного зростання [1]. Економіка, що заснована на знаннях та творчості, $є$ новою конфігурацією розвитку суспільства та висуває власні вимоги до функціонування різних типів ринків, у тому числі до ринку праці та вищої освіти. Перспектива суспільного розвитку у значній мірі залежить від вищої освіти [2, с. 7]. Освіта як основа довгострокової ефективної реалізації знань, здібностей та талантів людини відіграє одну із ключових ролей в управлінні розвитком креативного капіталу. 
На сучасному етапі розвитку розуміння капіталу як «потенціалу розгортання нового виробництва» [3, с. 21], здійснити який у повній мірі можливо лише за допомогою відповідних перетворень, є основою підходу до управління креативним людським капіталом. Виконання такої схеми на практиці у освітньому процесі означає, що різні здібності, навички, які притаманні людині, розвиваються, відтворюються у системі освіти як у механізмі, що направлений на зростання креативного людського капіталу. Здатність генерувати нові нестандартні ідеї та рішення перетворюється за допомогою методології, освітніх технологій, виховання у системі освіти, в кінцевому результаті втілюючись на практиці в оригінальних продуктах, технологіях та інноваціях. Провідна функція освіти у суспільстві інформації та знань визначається тим, що прогрес досягається не ситуативними мобілізаційними методами, а базується на особистісних та групових креативних ресурсах [4, с. 113]. Отже, на даному етапі розвитку суспільства, що характеризується постійно зростаючим значенням людського капіталу, пріоритетом стає формування, розвиток у людей якостей та здібностей, що відповідають потребам сучасного виробництва, ринку праці, економіки [5].

Креативні індустрії, набуваючи все більшого значення, стають основою для креативної економіки розвинених країн світу та країн, що розвиваються. Як правило, креативна індустрія першою освоює інноваційний ресурс, який відповідає на нові запити ринку. В таких умовах система освіти прогнозує майбутні зміни, зумовлюючи стратегічні напрямки розвитку галузей i формуючи системи підготовки кадрів для «креативних професій». Піонерами в цьому напрямку стали країни Свропи, які розробляють концепцію «креативних професій», визначаючи ті види індустрій, які потенційно можуть бути включені до креативного сектору економіки. При цьому перехід на цифрові технології формує нові вимоги до способи взаємодії, визначає появу нових гравців на ринку, формуючи пул інноваційних креативних послуг. Зміни, що відбуваються у цій сфері пов'язані з цілеспрямованими діями урядів країн світу. Найбільш успішними можна вважати європейські програми, такі як Програма ЄС «Креативна Європа» та Європейська ініціатива в сфері інноваційного розвитку дизайну. Партнерами програм є Великобританія, Бельгія, Данія, Естонія, Фінляндія, Франція, Ірландія, Італія, Польща, Словенія та Іспанія.

Навчання креативним підходам та виховання креативності - це дуже важливе завдання сучасної освіти. Адже саме від працівників сьогодні у першу чергу вимагається здатність до вирішення нестандартних завдань. У Свропі більшість педагогів вважають, що креативність $\epsilon$ базисною навичкою, яку повинна розвивати школа та університети. Сучасна українська система вищої освіти орієнтується на студентів, які відтворюють задані алгоритми дій, але практично не здатні до прийняття самостійних та ініціативних рішень. Отже, в Україні необхідно прискореними темпами змінювати ситуацію в сфері освіти, де іiі ціллю мають стати не лише знання та вміння, а й їх практичне застосування. В учбових планах потрібно збільшити кількість занять у проектних групах, адже саме такі види занять, а не лекції, виховують у студентів навички креативного мислення.

На жаль, у роки незалежності ми не мали можливості об'єктивно оцінювати освітній рівень наших учнів у порівнянні з їх однолітками $з$ інших країн. Для цього існує, наприклад, Програма 3 оцінки освітніх досягнень учнів або PISA. У програмі PISA беруть участь представники більш ніж 70 країн. Учні з таких азійських міст та країн як Шанхай, Гонконг, Сінгапур, Японія та Південна Корея останні роки здобувають найкращі місця. Серед європейських країн школярі 3 Фінляндії, Естонії та Польщі по багатьох показниках перебувають у десятці.

Україна має дуже високі показники грамотності населення - 99,7 \%, що на одному рівні, або навіть часом випереджаючи Японію (99\%) та Південну Корею (97,9 \%). Наскільки ці показники дозволять українським школярам успішно конкурувати з азійськими - покаже час. Згідно останнім повідомленням представників МОН України, Україна приєднається до PISA вже найближчим часом [6].

Україна має також достатній інноваційний потенціал, що є підтвердженням значного внеску освітньої складової у високі позиції України у світових рейтингах. Зокрема, за індексом людського розвитку Україна займає 84-те місце серед 188 країн і територій у 2016 році. Для порівняння Польща у цьому рейтингу займає 39 місце, Росія - 49, Білорусь - 52. За Індексом людського капіталу У 2016 році Україна зайняла 26 місце серед 130 країн світу [7]. Достатньо високий рейтинг України за загальним Індексом глобального таланту (Global Talent Index) 69 місце серед 118, а у субіндексі Global knowledge skills - 53-тє місце, але за показником середовища для талантів (ENABLE) — лише 103-тє. Крім цього, Україна входить у перші 50 iз 
123 країн за The Global Innovation Index 2017. При цьому в субіндексах цього рейтингу Knowledge\&technology Україна займає 32-ге і Human capital\&research 41-ше місце відповідно [8].

Як бачимо Україна має потужний потенціал креативної економіки, що може забезпечити економічне зростання як країни в цілому, так і окремих міст. Адже, за даними фахівців, через 57 років частка креативної продукції у ВВП може складати більше $10 \%$. Разом 3 тим, вплив професійної освіти на креативну економіку недооцінюється. Якщо освітня система не в змозі забезпечити потреби ринку праці, то створюються умови для відтоку молоді, зниження підприємницької ініціативи, зростання науково-технічних втрат і як результат - втрат економічних.

Як соціальний інститут, який відтворює інтелектуальний потенціал країни, освіта повинна мати здатність до випереджаючого розвитку, відповідати інтересам суспільства, конкретної особистості і потенційного роботодавця. Тут на перший план виходить принцип оцінки «професійної придатності» фахівця. Якщо раніше він оцінювався за ступенем своєї кваліфікації (знань і вмінь в рамках даної спеціальності), то тепер мова йде про компетенцію як здатності та вміння вирішувати всі завдання, що виникають в процесі професійної діяльності, а не тільки суто спеціалізовані. При цьому підвищення рівня складності сучасної університетської освіти визначає серйозність вимог до інтелектуального i культурного потенціалу студента [9].

Університети 3 їх історично сформованою структурою, кадрами (доктори та кандидати наук), зв'язками сьогодні є головним інтелектуальним потенціалом країни. В системі "наука - освіта - виробництво" університети займають центральне місце як генератор кадрів вищої кваліфікації. Отже, від їхнього рівня і стану розвитку як інтелектуального-креативного потенціалу суспільства залежить рівень і стан розвитку наукової, технічної та виробничої діяльності.

Випускники ВНЗ охоплюють всі сфери суспільства: економічну і соціальну, політичну і духовну, а відповідно, рівень їх підготовки, рівень загальної і професійної культури визначає і ефективність відповідних видів діяльності. Отже, університети є центром нового суспільства, та несуть відповідальність за формування інтелектуальної та креативної нації і подальший інноваційний розвиток країни [9].

Висновки. 3 метою реформування сучасної системи освіти Міністерство освіти і науки України розробило проект Концепції розвитку освіти на 2015-2025 роки. Зазначена концепція охоплює п'ять нових напрямків розвитку освіти, зокрема: Упродовж 2015-2020 років пропонується запровадити комплекс заходів, спрямованих на системне заохочення наукової та професійної активності викладачів, їх міжнародної та внутрішньої академічної мобільності, розширення практик творчих відпусток та стажування за кордоном. Концепцією розвитку освіти пропонується добитись до 2020 року поетапного запровадження участі іноземних викладачів у навчальному процесі українських університетів, опанування вітчизняними викладачами новітніми інтерактивними, індивідуалізованими, командними та проектними навчальними технологіями. П'ятим напрямом Концепції розвитку освіти є «реорганізація системи управління, фінансування та менеджменту освіти шляхом децентралізації, дерегуляції, запровадження інституційної, академічної та фінансової автономії навчальних закладів, дотримання принципу відповідальності навчальних закладів за результати освітньої та виховної діяльності».

Автори розробленого документу зазначають, що «планується перегляд обсягу і меж повноважень центральних і місцевих органів управління освітою, скорочення контрольнонаглядових функцій, жорстка і чітка регламентація процедур і повноважень інституцій, пов'язаних з контролем і наглядом». За два роки планується реорганізувати районні управління та відділи освіти у сервісні центри, а ще - залучити громадські, батьківські та наглядові ради, які матимуть повноваження для ініціювання відкликання керівництва навчального закладу. Україні потрібна системна реформа освіти, оскільки освіта в цілому є одним 3 основних важелів цивілізаційного поступу та економічного розвитку [10].

Майбутнє України буде визначатися підростаючим поколінням, саме тому важливим завданням системи освіти $є$ виявлення та розвиток у молоді потенційних здібностей та талантів. Сучасному світу, в тому числі і українському суспільству, потрібна особистість, яка здатна до самостійного, творчого та інтелектуального розвитку.

Безперервність і глибина інноваційних процесів у вищих навчальних закладах 3 особливою гостротою ставить проблему особистісного і творчого розвитку майбутнього фахівця, формування інтелектуального потенціалу студента і націлює на пошуки нових шляхів і підходів. Ця діяльність повинна бути спрямована на:

- створення умов для розвитку творчої, незалежної, соціально відповідальної особистості, що володіє високою професійними вміннями та знаннями; 
- поєднання освітніх і культурних складових, інтеграція навчання з дослідженням;

- підтримка високих академічних стандартів, традицій, ціннісних орієнтацій як провідних цінностей університетської культури;

- створення творчого середовища, підтримку індивідуалізованих форм підготовки, 3 акцентом на самоосвіту і самовиховання [9];

- розширення і вдосконалення університетських освітніх програм через інформаційні технології, через ознайомлення 3 напрямами науки, через ознайомлення 3 проблемами сьогоднішнього дня, включення студента в світовий науковий і освітній простір;

- створення середовища, що стимулює у студента формування активної життєвої позиції та можливості реалізації свого особистісного і творчого потенціалу.

\section{ЛITEPATУРА}

1. Glaeser E. L. Review of Richard Florida's "The Rise of the Creative Class" 2004 Retrieved from: https://scholar.harvard.edu/files/glaeser/files/book review of richard floridas the rise of the creative class.pdf

2. Schultz T. W. Investment in Human Capital: The Role of Education and of Research. N. Y., 1971. 272 p.

3. Сото, Э. де. Загадка капитала. Почему капитализм торжествует на Западе и терпит поражение во всем остальном мире. М., 2004. 272 с.

4. Леньков Р. В., Пацула А. В. Социологическое прогнозирование в сфере высшего образования // Методологические проблемы междисциплинарных исследований в сфере наук об образовании: материалы науч.-практ. конф. с междунар. участием, посвящ. 90-летию акад. РАО В.В. Краевского. Тула, 2016. С. 111-115.

5. Матраева, А. Д. Роль высшего образования в управлении креативным человеческим капиталом [Электронный ресурс]. - Режим доступа: https://cyberleninka.ru/article/n/rol-vysshegoobrazovaniya-v-upravlenii-kreativnym-chelovecheskim-kapitalom

6. Україна у глобальних рейтингах: підсумки 2015 року [Електронний ресурс]. - Режим доступу: https://www.pravda.com.ua/cdn/graphics/rating/story/

7. Рейтингові оцінки розвитку людського капіталу 2016 [Електронний ресурс] / Економічний дискусійний клуб. - Режим доступу: http://edclub.com.ua/analityka/reytyngoviocinky-rozvytku-lyudskogo-kapitalu-2016

8. Україна в міжнародних економічних рейтингах [Електронний ресурс] / M Consulting Group. - Режим доступу: http://m-cg.com.ua/ua/ukraine-world-index-2016-2017/

9. Нуриев, М. А., Сейсенбаева, Ж. А., Мырзаханова, И. А., Садыкова, А. Е. Теоретические основы формирования интеллектуальной нации в условиях высшей школы как условие инновационного развития РК [Электронный ресурс]. - Режим доступа: https://www.fundamental-research.ru/ru/article/view?id=31213

10. Проект Концепція розвитку освіти України на період 2015-2025 років [Електронний ресурс]. - Режим доступу: http://tnpu.edu.ua/EKTS/proekt_koncepc.pdf 